\title{
A CASE FOR ASSESSING ALLOCASUARINA AND CASUARINA SPP. FOR USE IN AGROECOSYSTEM IMPROVEMENT IN SEMI-ARID AREAS WITH A FOCUS ON CENTRAL ANATOLIA, TURKEY
}

\author{
Ian T. RILEY ( $\triangle)$
}

Department of Plant Production and Technologies, Faculty of Agricultural Science and Technologies, Niğde Omer Halisdemir University, Niğde 51240, Turkey.

\section{KEYWORDS}

actinorhizal trees, agroforestry, climate change, ecosystem restoration

\section{HIGHLIGHTS}

- Semi-arid ecosystems have been especially impacted by a long history of clearing, cropping and intensified grazing.

- Selection of tree species for assessment for agroforestry needs to consider their utility and effectiveness in provision of ecosystem service, but also the wider consideration of preserving biodiversity.

- Imperatives of agroecosystem services and biodiversity conservation (or restoration) will impact on species selection for agroforestry.

- The potential of Allocasuarina and Casuarina for wider economic and ecosystem needs an endeavor to achieve demonstrable gains.

Received April 11, 2019;

Accepted May 5, 2019.

Correspondence: ian@riley.asia

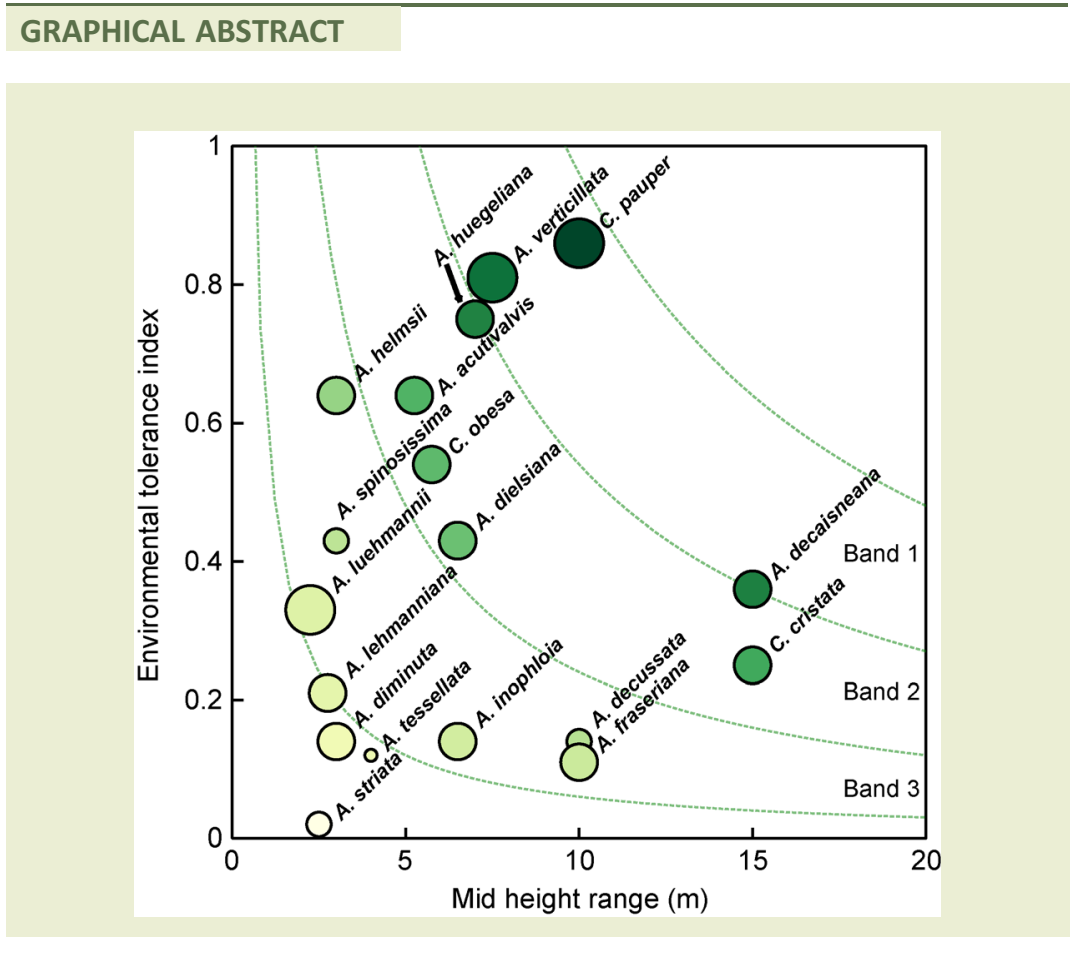

\section{ABSTRACT}

Agroecosystems in water-limited contexts - Mediterranean, semi-arid and arid climatic zones - are too frequently degraded systems that will not provide the needed ecosystem services to ensure a future of sustainable agricultural production. The processes that have created this situation continue and are being accelerated by anthropogenic climate change. Increasing arboreal vegetation in these areas through agroforestry is an important strategy to conserve and improve their agroecosystems. Actinorhizal trees and shrubs in the Casuarinaceae have a unique set of adaptations for heat and water stress, and/ or infertile to hostile soils. Central Anatolia, Turkey is particularly at risk of increasing aridity and further degradation. Therefore, species of Allocasuarina 
and Casuarina have been evaluated for their potential use in agroecosystem improvement in semi-arid areas with a focus on Central Anatolia. Based on a semiquantitative environmental tolerance index and reported plant stature, eight species were identified as being of high ( $A$. verticillata and $C$. pauper) to moderate ( $A$. acutivalvis, $A$. decaisneana, A. dielsiana, A. huegeliana, $C$. cristata and $C$. obesa) priority for assessment, with none of these species having been adequately evaluated for agroforestry deployment in semi-arid agroecosystems in any context.

(C) The Author(s) 2019. Published by Higher Education Press. This is an open access article under the CC BY license (http://creativecommons.org/licenses/by/4.0)

\section{INTRODUCTION}

The importance of agroecosystem services for the future of sustainable agricultural production is increasingly recognized. With the development of transhumant and sedentary agriculture, the pre-agrarian ecosystems were changed irreversibly by land cleaning, cultivation and intensified grazing into what are now known as agroecosystems. Although simpler systems with a high degree of anthropogenic alteration, agroecosystems can be sustainable and productive. However, with the intensification of agricultural production during the 1900s, including increased use of mechanization, fertilizers and agrochemicals, improvement and consequent narrowing of crop genotypes, loss of remnant native vegetation, larger farms and declining rural populations, many agroecosystems are now considered degraded. There is clear need for improvement of these systems to ensure future sustainability, especially if increased production levels are to be realized or even current levels maintained.

Biologically diverse agroecosystems can provide many beneficial ecological services that can reduce the need for off-farm inputs to improve the economic efficiency of agriculture production and reduce negative environmental impacts, locally, regionally and globally. For example, conservation agriculture with no (or minimal) cultivation can reduce fuel inputs, compaction, erosion, run-off and evaporation, but most importantly it can increase soil organic matter and thereby diversity of soil organism benefiting nutrient cycling and root health. Likewise, increasing agroecosystem biodiversity through crop and cultivar rotations can be beneficial for weed, pest and pathogen control, and biological nitrogen-fixation. Increasing the biodiversity of perennials, such as trees, can provide habit and refuge for organisms beneficial to integrated pest management, as well as for native flora and fauna, as well as moderate microclimate for reduced wind damage and evaporation rates.

Restoration and/or improvement of agroecosystems, although clearly a worthy, if not essential, undertaking, is not something that can be achieved simply or quickly. Indeed, the degradation of agricultural land and environments is a multi-causal problem with constantly changing dynamics and many stakeholders. It has been described as a wicked (highly complex) problem; such problems have no single solution, and many barriers for finding and implementing solutions, with some attempted solutions actually exacerbating the problem ${ }^{[1]}$. These problems are considered to be unsolvable, and not even understandable, by a single organization, with consensus between organizations on causes and solutions unlikely. So a range of possible partial solutions need to devised and tested by different contributors both collaboratively and independently.

Restoration of semi-arid environments in urban, agricultural, pastoral and non-production (including protected areas) contexts is particularly problematic. Low rainfall means the productivity of the systems is low, so biological processes take longer to achieve. Semi-arid areas generally have naturally less fertile soil, which is alkaline to depth with consequences for nutrient availability ${ }^{[2]}$, a higher frequency of drought ${ }^{[3]}$ and other constraints to restoration. Also, the on-going processes of degradation, erosion, nutrient and organic matter depletion ${ }^{[4]}$, and declining biodiversity, mean that restoration efforts have to built on shifting sands (metaphorically and sometimes even literally). In addition, agriculture in semi-arid areas is generally less productive, so returns on investment in ecosystem restoration will be lower and risks higher than in higher rainfall areas. However, a major proportion of the world's food production is in low-rainfall areas ${ }^{[3]}$, so despite the economics the need is imperative.

Turkey has large areas of semi-arid agriculture, especially in Central Anatolia which is classified as an anthropogenic steppe with a semi-arid continental climate ${ }^{[5]}$. Sedentary farming and grazing in the region has been practiced for an extended period dating back to the Neolithic Revolution with one of the earliest proto-cities, Çatalhöyük (Çatalhöyük Research Project website), having been unearthed on the Konya Plain. The impact has been major changes in vegetation and the almost complete deforestation of the region ${ }^{[6,7]}$. So the current agroecosystems will bear 
little resemblance to the former pre-agrarian ecosystems. Upslope soils will have been truncated and improvised, and downslope accumulating areas completely changed. The loss of the ancient forests is also likely to have impacted on aspects of climate $^{[8]}$ including temperatures (particularly soil temperatures) and rainfall (which has been documented for contemporary Mediterranean and tropical climate deforestation $)^{[, 10]}$. Consequently, reversing the degradation of Central Anatolian ecosystems and the establishment of a productive and sustainable agroecosystem is a complex matter.

Reafforestation has been actively pursued in Turkey for some decades, however, Lund ${ }^{[1]}$ suggested that up-to-date statistics are not readily available and that there are some definitional uncertainties. Nevertheless, it is identified as a key element of the national climate change $\operatorname{plan}^{[12]}$. However, an impetus for economic agroforestry and using trees in agroecosystem restoration has not been given any particular priority. Various kinds of agroforestry are part of the traditional farming systems, but these have only minimal recognition in academic and institutional programs ${ }^{[13]}$. Tree planting in Turkey has been mostly for silviculture purposes and amenity (protection) plantings (e.g., associated with major road construction and as buffer planting around urban areas), rather than with specific agroecosystem goals. Consequently, tree plantings have almost always been direct planting of the desired species for the longterm. This might mean that the process has been less than optimal, as species selection was based on the benefits offered by the mature planting rather than the benefits offered by a successional process.

Lingley and Jazdzewski ${ }^{[14]}$ bemoaned the fact that in the case of mining site rehabilitation, that institutions, even those fully aware of ecological principles, demanded climax flora to be established immediately. The same erroneous expectations have applied to reafforestation and agroecosystem restoration. Krawczyk $^{[15]}$ addressing this issue, states that restoration of sustainable forest ecosystems requires an ecological succession using early-colonizing (pioneer) species. The analysis of Prach and Hobbs ${ }^{[16]}$ shows that for high-stress contexts (such as semiarid regions of Turkey) contrived ecological succession is more likely to be successful. Though given the extended timelines for achieving agroecosystems objectives in semi-arid contexts, it is not surprising that succession approaches are not common. The FAO guidelines for restoration in drylands talks about assisted natural regeneration using methods to accelerate natural succession $^{[17]}$, mentions the planting of pioneer grasses, but does not mention planting woody nurse species or pioneers as an initial step in an assisted succession.

The planting of woody pioneers for semi-arid area restoration, although a long-term strategy, is an approach that should be the subject of more consideration and research. For the Central Anatolian context, the concern is that without action, current trends, accelerated by global warming, could lead to widespread desertification ${ }^{[18,19]}$. Given that Turkey does not currently have deserts (Table 1), the native woody pioneers are less likely to be suitable for succession restoration than species from more arid countries. One source of suitable species might be the semi-arid areas of Australia, a continent that is mostly semi-arid to arid (Table 1; Fig. 1) with many plant taxa having adaptations enabling survival and growth in infertile soils ${ }^{[21]}$. Also, the continent's arid areas are generally well vegetated with species able to tolerate fluctuations in water availability and severe water stress $^{[21]}$.

The aim of this paper is to consider the merits of wider evaluation of species of Allocasuarina and Casuarina for semiarid ecosystem improvement. These genera have species with adaption for arid climates that overlap those currently in Turkey (Fig. 1(b)), but also for more arid climates that might develop in Turkey with climate change. Therefore, the focus of this paper is the agroecosystems of semi-arid cropping areas in the cold semiarid climate (BSk, Fig. 1(b)) of Central Anatolia, Turkey. It is not

Table 1 Comparison of arid and semi-arid agroecological zones between Australia and Turkey

\begin{tabular}{lccccc}
\hline \hline \multirow{2}{*}{ Agroecological zone } & \multicolumn{3}{c}{ Australia } & & \multicolumn{2}{c}{ Turkey } \\
\cline { 2 - 4 } \cline { 3 - 5 } Desert/arid & Area (ha) & Proportion (\%) & 40.4 & Area (ha) & Proportion (\%) \\
Dry, good soils & 319012 & 0.6 & 14 & 0 \\
Dry, moderate soils & 4700 & 15.6 & 2310 & 2.9 \\
Dry, poor soils & 122784 & 22.6 & 17589 & 21.9 \\
Total arid/semi-arid & 178600 & 79.2 & 32598 & 12685 \\
\hline \hline
\end{tabular}

Note: Source from International Institute for Applied Systems Analysis (IIASA) website. 


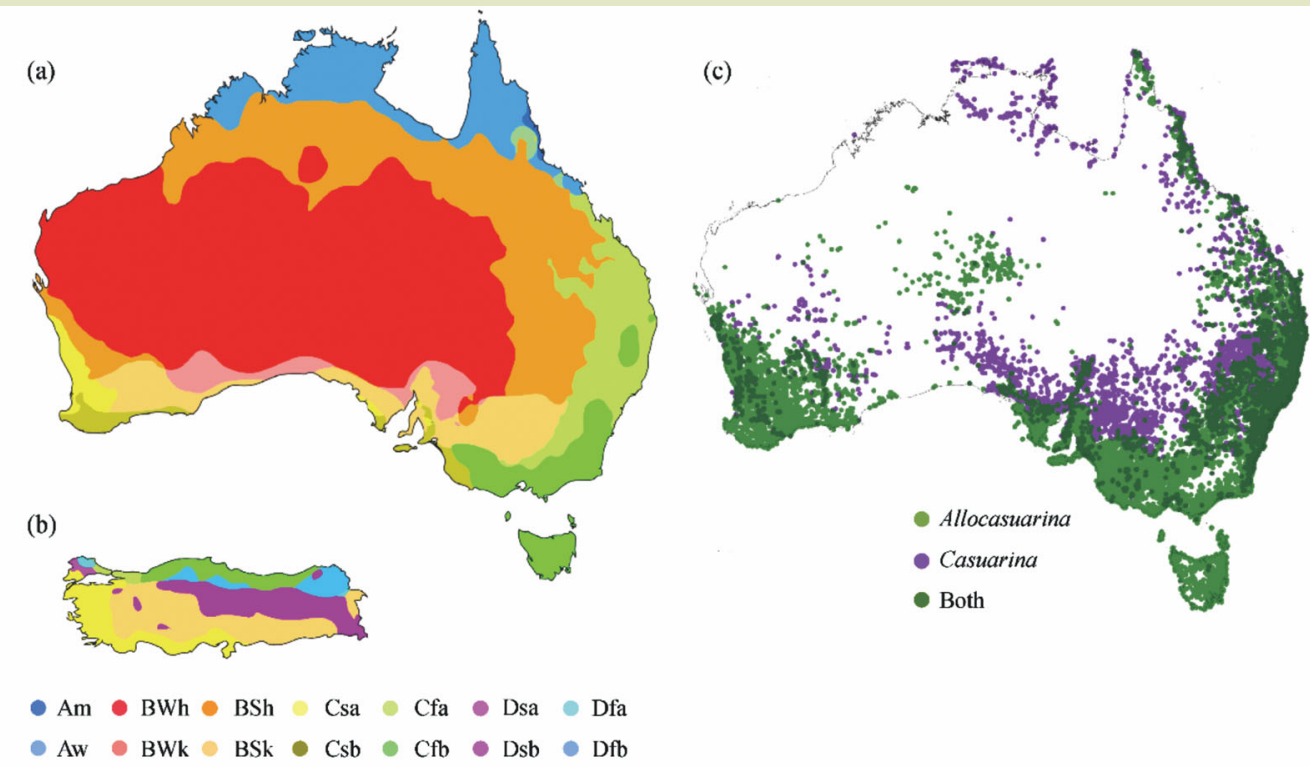

Fig. 1 Köppen climate classification for Australia (a) and Turkey (b), and the distribution of records of Allocasuarina and Casuarina spp. in Australia (c). Köppen climate codes: Am, tropical monsoon; Aw, tropical wet and dry; BWh, hot desert; BWk, cold desert; BSh, hot semi-arid; BSk, cold semi-arid; Csa, hot-summer Mediterranean; Csb, warm-summer Mediterranean; Cfa, humid subtropical; Cfb, temperate oceanic; Dsa, Mediterranean-influenced hot-summer humid continental; Dsb, Mediterranean-influenced warm-summer humid continental; Dfa, hot-summer humid continental; Dfb, warmsummer humid continental (source from Peel et al. ${ }^{[20]}$ ). Plant distribution map source from Atlas of Living Australia (ALA) website (accessed on July 18 , 2018).

intended to provide a comprehensive summary of the botany and ecology of the target species or their microbial associates here, and readers who need more detail on these are directed to the Flora of Australia (pp. 100-174) ${ }^{[22]}$ for systematics, a monograph on the history of Australian flora (pp. 407-409) ${ }^{[23]}$ for paleontology, and the proceedings of the five international workshops $^{[24-28]}$ for use in silviculture and agroforestry, and a recent review of the biogeography and ecology of the genus Casuarina $^{[29]}$. Likewise, for detailed aspects of agroforestry, readers should refer to an excellent monograph on the subject, Agroforestry for Natural Resource Management ${ }^{[30]}$.

\section{ECOLOGICAL STATUS OF SEMI-ARID CROPPING AREAS}

Semi-arid ecosystems have been especially impacted by a long history of clearing, cropping and intensified grazing. It is likely that the impact will have been greatest in areas were dryland agriculture has been practiced for millennia. However, even in Australia, where large scale land clearing is relatively recent, the magnitude of the impact in semi-arid areas has been enormous $^{[31-34]}$. There has been considerable loss of local biodiversity, high rates of species extinction and loss of habitat for native flora and fauna. In addition, large numbers of invasive plant species have been introduced, with many agroecosystems dominated by exotic species. Also, introduced herbivores (domestic livestock and feral rabbits) and predators (foxes and feral cats) have impacted on native plants and animals. There has also been considerable soil loss through wind and water erosion, and soil degradation through dryland salinity and loss of organic matter ${ }^{[35,36]}$. Given the nature and scale of impact in Australia has been so great in such a relatively short time, the impacts in areas such as Central Anatolia must have been equally or even more severe.

Central Anatolia has a long history of agricultural impact, that includes periods of abundance and famine, aridity, erosion, deforestation and reforestation, and abandonment and recolonization $^{[37,38]}$. Periods of warmer and drier climate have had devastating effects and are considered to have been driven by global processes ${ }^{[37]}$. However, it is not inconceivable that localized effects of deforestation ${ }^{[10]}$ also contributed to Anatolian agroecosystems being vulnerable to climate change. With Anatolia now seen as being at particular risk from anthropogenic climate change and other human impacts ${ }^{[18,39]}$, it should be a priority region for agroecosystem improvement. There is not only an economic impetus for this, but it would also help conserve Central Anatolian flora ${ }^{[40]}$ and fauna. Although the Central Anatolian climate is considered the least favorable for 
tree growth in Turkey, the loss of arboreal vegetation appears to have been mostly anthropogenic ${ }^{[41]}$, so aspirations to reverse of this situation should not be seen as unachievable.

Indeed, the Republic of Turkey Climate Change Strategy 2010 $2023^{[12]}$ recognizes the importance of increasing tree populations in the semi-arid areas of the country. For its green gas emission control, it sets a medium-term goal to identify and plant drought tolerant trees, especially in the arid and semi-arid areas; vegetation activities will be carried out in the areas in which afforestation is difficult and costly. Additionally, for adapting to climate change, it sets a short-term goal to develop and expand activities to combat desertification and erosion, which undoubtedly would involve increasing the resilience of marginal agroecosystems by planting drought tolerant trees. These and other short-, medium- and long-term goals, relate to agroecosystems, however, the plan does not explicitly identify agroforestry as a strategy. Whereas, the FAO in its Save and Grow $^{[42]}$ proposal for a new paradigm of intensive crop production explicitly identifies agroforestry as an important strategy for rebuilding robust and productive agroecosystems, especially in semi-arid environments. Both the Republic of Turkey and the FAO see semi-arid agroecosystems as degraded or at high risk of degradation, and urgently in need of active improvement.

\section{POTENTIAL FOR TREES IN AGRO- ECOSYSTEM IMPROVEMENT}

By definition the key plants and animals in agroecosystems are economically-beneficial domesticated species, including trees grown for fruit, nuts, forage, fuel and timber. However, the majority of the biodiversity in agroecosystems will be wild species, both indigenous and exotic, including microflora, annual and perennial plants, resident and non-migratory invertebrate and vertebrate animals. Many exotic species will be economically-damaging species (plant and animal pathogens and parasites, herbivorous invertebrates and vertebrates, invasive weeds and predatory animals), but also some indigenous species ${ }^{[43]}$ will have negative economic impacts in agricultural systems, particularly in areas where agriculture developed in antiquity. Although trees usually only represent a small proportion of the overall biodiversity in agroecosystems, their ecological and economic benefits can be substantial, and increasingly well recognized ${ }^{[30]}$.

Trees are woody perennials that generally grow to over $5 \mathrm{~m}$ tall and, therefore, have impact in vertical space unlike most other plants in agroecosystems. Also, with height also comes depth, so trees have roots systems that explore deeper into the soil than most annuals or smaller perennials. Therefore, trees provide a uniquely large range of ecosystem services. Their height can reduce surface wind speeds and wind erosion, provide shade for domestic animals as well as habitat and refuge for native animals (including invertebrates), favorably moderate the local microclimate, and even increase atmospheric water capture and precipitation rates ${ }^{[4]}$. Being large perennials, they can be productive contributors to carbon sequestration, and increase soil and surface organic matter, and a source of economically useful materials other than food (timber, fuel, fodder and more). The deeper roots extract and cycle nutrients and utilize water resources not available to other plants. The benefits of trees range from local climate, biodiversity and economics through to regional and global climate. Of course, trees in agroecosystems can also compete with crops, increase fire risk, reduce ground and surface water storage, and even be a source of allergens impacting on human health. However, on balance, trees offer great potential for agroecosystem improvement.

Realizing the potential benefits of increased tree populations in agroecosystem is a slow and uncertain process ${ }^{[45]}$, but nevertheless is seen as crucial for the future of food production ${ }^{[42]}$ and the maintenance of biodiversity, and other conservation objectives, in an increasingly anthropogenically impacted world. Unlike the main agricultural crops, which consist of a relatively small range of species, there is estimated to be over 60000 tree species with about $15 \%$ considered to be in danger of extinction ${ }^{[46]}$. So clearly, using trees for agroecosystem improvement can also directly and indirectly (by slowing or preventing the on-going expansion of agricultural land) help in the conservation of tree species. Thus, the selection of tree species for assessment for agroforestry needs to consider their utility and effectiveness in provision of ecosystem service, but also the wider consideration of preserving biodiversity.

\section{SPECIES SELECTION FOR AGROECO- SYSTEM IMPROVEMENT}

Imperatives of agroecosystem services and biodiversity conservation (or restoration) will impact on species selection for agroforestry. To maximize biodiversity benefits, it is recommended that locally indigenous species are planted with an understory of local shrubs, because this is likely to be best for conservation of local wildlife ${ }^{[47]}$. This recommendation is also built on the assumptions that locally indigenous species (1) will be adapted to the local environment, (2) can provide the desired agroecosystem services, and (3) are practically and economically suitable for propagation and established. Salt and 
Freudenberger $^{[47]}$ acknowledged that in some circumstances local species might not be suitable in contexts where conditions have been altered, and they cite dryland salinity as such a situation.

Thousands of years of anthropogenic impact have significantly altered conditions in Central Anatolia, so the concept of exclusively or preferentially using locally indigenous species is unlikely to apply to the extent that it does in countries like Australia. In addition to altered conditions, there are also other reasons that local species might not be the optimal choice. For example, in the Australian context, they might increase fire risk and in the Turkish context, some of the local species are already in serious decline from biotic and abiotic stress, so attempts to reintroduce local species to agricultural areas might not always be successful. For examples, indigenous Quercus spp. ${ }^{[48,49]}$, Abies cilicica $^{[50]}$, and Populus nigra ${ }^{[51]}$ are all in decline in Turkey due to pests and/or diseases, increasing aridity and genetic introgression, therefore selection of these species for agroforestry may not achieve biodiversity and ecosystem service goals.

Some indigenous species are already being used or considered for ecological rather than silvicultural purposes in Central Anatolia, and the challenge of species selection is well recognized $^{[52]}$. Large areas of trees have been planted for revegetation purposes since the 1960s, but often with limited success that is considered to be due to inadequate research ${ }^{[52]}$, particularly in species selection. In the study of Yildiz et al. ${ }^{[52]}$, Elaeagnus angustifolia was considered to offer significant potential for arid land reafforestation. Notably, this species is considered a seriously invasive species in Canada and the USA, and well adapted to infertile soil because its roots are nodulated by the nitrogen-fixing actinomycete, Frankia ${ }^{[53]}$. Mostly, Pinus nigra, has been planted, but its survival and growth can be far from optimal, especially in sites with greater water stress ${ }^{[52]}$, so a range of other indigenous species are under consideration ${ }^{[54]}$.

Local growing-conditions have changed in deforested areas, but importantly they are also subject to on-going climate change. In Central Anatolia increased aridity is predicted, therefore, species selection for reafforestation also needs to consider future conditions. This is well illustrated by the loss of anthropogenically-distributed trees in sub-Saharan Africa due to climate change ${ }^{[55]}$. Given that Turkey does not have highly arid areas, some exotic species might need to be considered. If this concept is accepted, pioneer species from the semi-arid and arid areas of Australia could be considered. There are nearly 3200 tree species in the Australian biome $e^{[46,56]}$ with many from the continent's large areas of arid land (Fig. 1). In contrast, Turkey has only about 185 tree species ${ }^{[56]}$, so the Australian biome undoubtedly offers a potential resource for tree species for agroforestry in Turkey.

Exotic species are axiomatically considered unacceptable in biodiversity restoration programs in natural environments, but this should not be the position taken for agroecosystem improvement. In most instances agriculture species are exotic, but nevertheless valuable. Likewise, trees species for agroforestry should not be limited to indigenous species ${ }^{[57]}$. Exotic species may be of direct value, but can also be used as pioneers in a technical succession to a predominately indigenous biome, especially in high-stress contexts, such as Central Anatolia ${ }^{[16]}$. In fact, the vast majority of global ecosystems are anthropogenically modified $^{[58]}$ and this process is predicted to continue with historical ecosystems going through transition to novel ecosystems. Even valued anthropogenic landscapes are subject to this change and can become the focus of conservation efforts (e.g., Thomas and Palmer ${ }^{[59]}$ ). So there exists a tension between preserving the existing and ensuring that the inevitablynovel agroecosystems of the future will provide the needed services.

Boydak and Çalışkan ${ }^{[54]}$ prudently state, “... for the exotic species not tested yet, decision[s], concerning whether they should be planted on the afforestation sites in semi-arid and arid areas, should be made after conduction [sic.] of essential adaptation trials...". So in summary, it is widely agreed that Central Anatolia needs more trees, and here it is proposed that tree species from the semi-arid to arid regions of Australia be assessed for this purpose. One group of Australian trees worthy of particular consideration in this regard is the sheoaks (F. Casuarinaceae), many of which are trees (and large shrubs) that grow in high stress environments.

\section{AGROECOSYSTEM POTENTIAL OF ALLOCASUARINA AND CASUARINA}

In Australia, the Casuarinaceae consists of species in three genera, Allocasuarina, Casuarina and Gymnostoma, with 61,6 and 1 species, respectively. Allocasuarina and Casuarina are found throughout Australia with distributions extending into Mediterranean, semi-arid and arid climate zones (Fig. 1), and all have foliar and root adaptions that enable them to grow in relatively harsh environments and infertile soils. In the former two genera, there are 29 species of trees and shrubs $(>3 \mathrm{~m})$ that are considered here (Table 2; Fig. 2) for their potential use for agroecosystem improvement in semi-arid areas outside Australia, specifically in Central Turkey.

Australian sheoaks have already been widely adopted for 


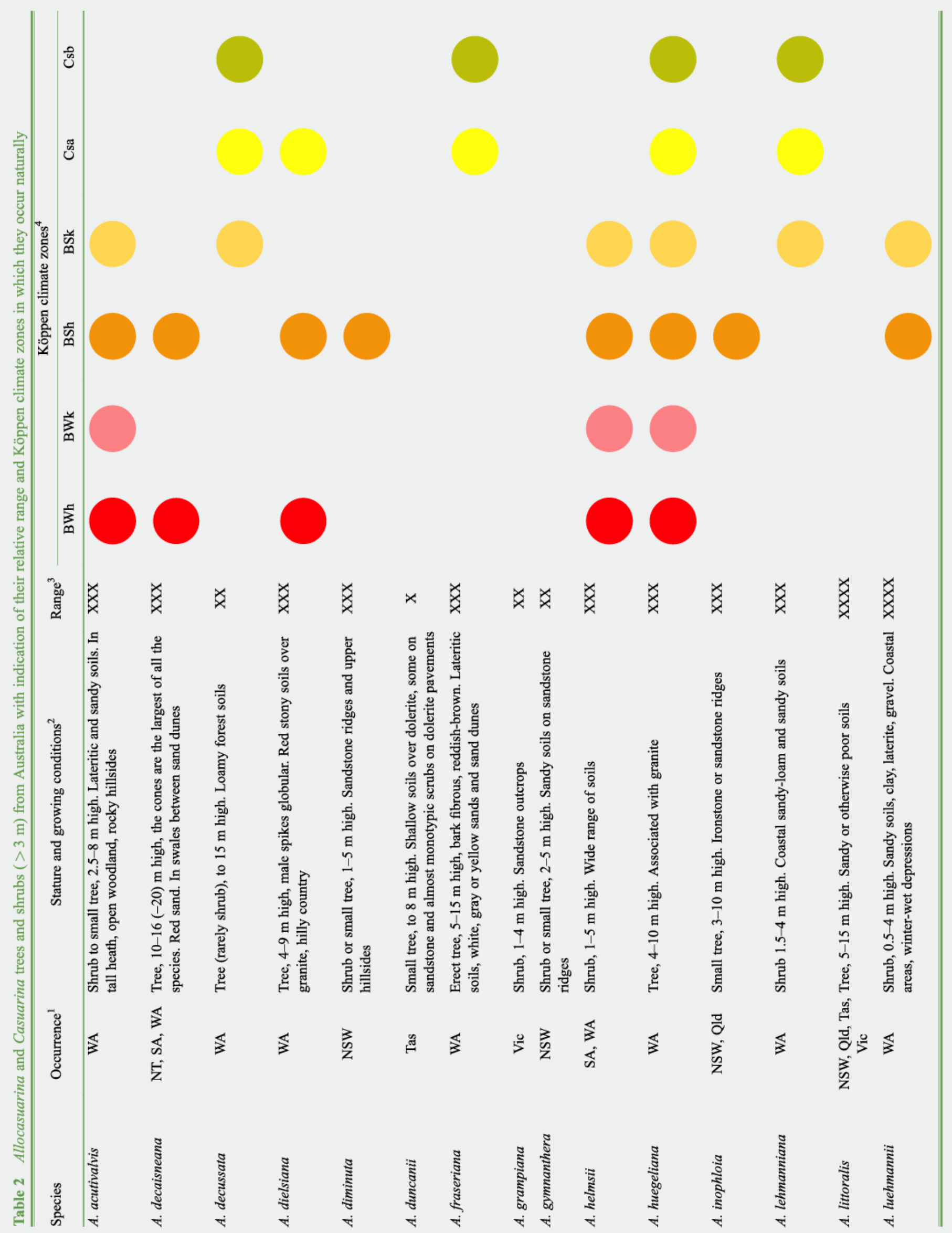




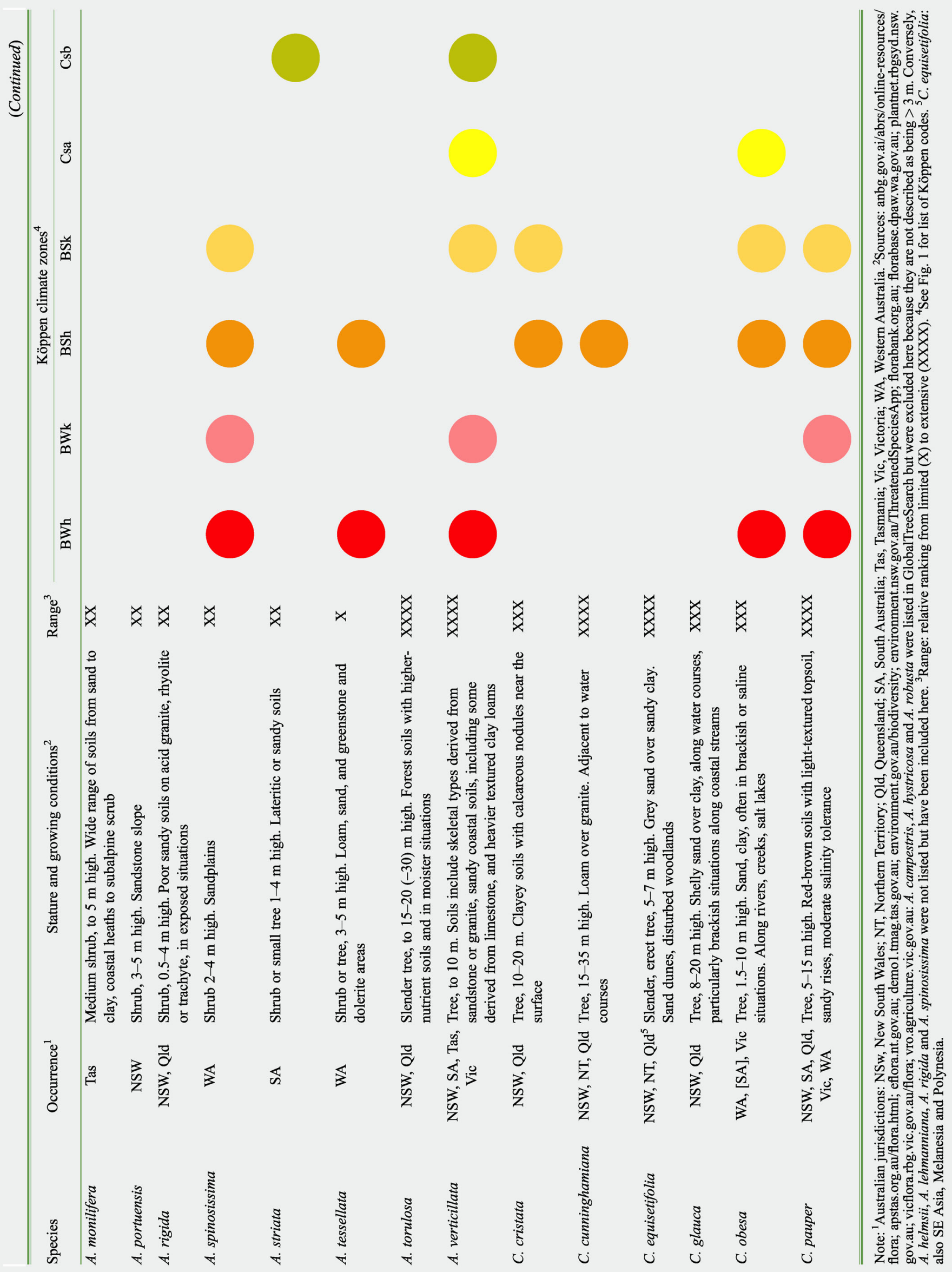




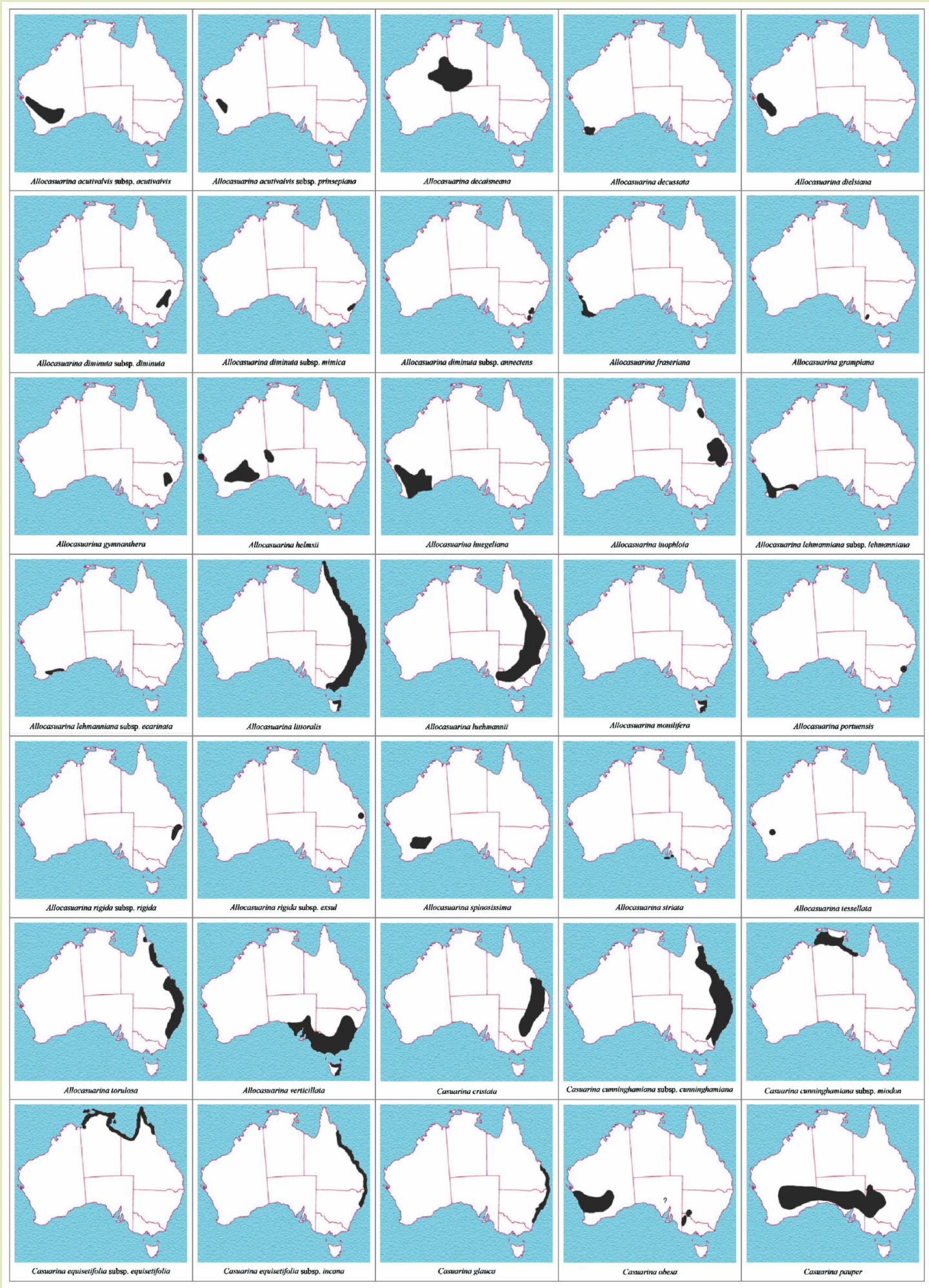

Fig. 2 Australian endemic distribution of Allocasuarina and Casuarina trees and shrubs (>3 m). Some species (viz., A. acutivalvis, A. diminuta, A. luhmanniana, A. rigida, C. cunninghamiana and C. equisetifolia) have recognized subspecies and these are shown on separate maps. A map of A. duncanii is not included, but it is a rare species with highly restricted distribution in south-eastern Tasmania. Source from Australian National Botanic Gardens (ANBG) website (pnid = 38582), which uses data derived from Flora of Australia volume $3^{[22]}$, and is a product of Australian Biological Resources Survey, (C) Commonwealth of Australia. 
forestry, agroforestry and other purposes in east, south and south-east Asia, mostly in subhumid to humid contexts with lesser use in semi-arid to arid contexts ${ }^{[28]}$, and also in Africa including some relatively low-rainfall contexts ${ }^{[60]}$. Most research and deployment has been with three Australian species (C. cunninghamiana, C. equisetifolia and C. glauca) and one Indonesian species (C. junghuhniana), being the larger more productive species. These species are not found naturally in lower rainfall areas (Table 2; C. cunninghamiana does extend into some hot, semi-arid areas in Queensland, but only along inland water courses), although C. equisetifolia and C. glauca are considered to exhibit useful drought tolerance ${ }^{[61,62]}$. Some Allocasuarina spp. have been used in Africa, viz. A. littoralis, A. torulosa, A. verticillata ${ }^{[60]}$, but only $A$. verticillata occurs naturally in low-rainfall areas (Table 2). A wider range of Allocasuarina species was introduced to China ${ }^{[63]}$, but there is no information on their adoption.

In the above contexts sheoaks have commonly been adopted for silvicultural purposes, however, they also can provide a wide range of other economic and ecological benefits. In introducing guidelines for restoration of arboreal vegetation in dryland areas, the FAO classifies these diverse benefits as provisioning, regulating, habitat (supporting) and cultural services ${ }^{[17]}$ to indicate the breath of economic, environmental and ecological services, and even benefits for a society's sense of well-being. Of course, the value of these services is greatest where they in shortest supply - degraded dryland environments. Among the many plant species that could contribute to restoration of semiarid areas, Allocasuarina and Casuarina hold some unique potential, but this potential needs to be balanced against any potential risks of introducing exotic species to new environments $^{[29,64]}$.

\subsection{Adaptive advantages}

Allocasuarina and Casuarina species have a range of biological and ecological features potentially making them suitable for agroecosystem improvement in harsh environments. These include their unique set of above- and below-ground adaptations, and their ability to be primary colonizers of disturbed and infertile (in the broadest sense) sites, and to persist as dominant species in sites unsuited to other arboreal species.

Allocasuarina and Casuarina have narrow elongated photosynthetic internodes (branchlets) with leaves reduced to small scales at the nodes, with stomata positioned deep within longitudinal stem grooves and a waxy surface ${ }^{[65]}$. In species more highly adapted to aridity, these grooves contain a large number of epidermal trichomes to further control evapotranspiration ${ }^{[65]}$. So sheoaks do not having foliage consisting of photosynthetic leaves, but rather a crown of dropping photosynthetic branchlets ${ }^{1)}$, which is a key feature providing adaption for heat and water stress. The narrow, pendulous branchlets of low horizontal surface avoids overheating from incident sunlight and radiant heat. The position of stomates in stem grooves, filled with epidermal hairs in some species, facilitates reduced evapotranspiration under water stress. The nature of the crown (including the waxy surface) can also limit damage in contexts of high wind speeds and salt laden ocean spray. As the branchlets function as leaves, they are not all retained, with most being shed by cladoptosis, and as the branchlets are more fibrous than most leaves this leads to a thick, slowly degrading mulch layer ${ }^{[66]}$. This mulch can be beneficial a water-limited environment by reducing competition from other plants, particularly annuals, and by improving water infiltration and reducing run-off below the canopy, and reducing $\mathrm{pH}$ of the mostly alkaline ${ }^{[2]}$ arid-zone soils.

Although the above ground features of sheoak are ecologically significant, and make these taxa distinctly recognizable, it is their below-ground adaptations that particularly justify their assessment for agroecosystem restoration in the more arid environments. They are deep-rooted perennials well adapted for seasonal and/or environmental aridity ${ }^{2}$. Their nodulation by nitrogen-fixing Frankia ${ }^{[68]}$, development of cluster roots (functionally similar to proteoid roots in the Proteaceae) ${ }^{[69]}$ and colonization by symbiotic mycorrhizal fungi, both vesiculararbuscular mycorrhiza and ectomycorrhiza ${ }^{[70]}$ for the infertile, and sometimes hostile, soils of semi-arid areas (as are common in Central Anatolia) ${ }^{[71]}$ are additional advantages.

As a consequence of these morphological and microbial features, sheoaks function in their native ecosystems in ways that also indicate their potential for use in agroecosystems. Casuarina spp. in the more temperate environments are pioneer species of disturbed and infertile sites ${ }^{[69]}$ and three species have become problematic invasive species in some subhumid to humid contexts around the world ${ }^{[72-74]}$. A. littoralis has, even within its native range, been described as an understory weed in the context of eucalypt forest decline ${ }^{[75]}$. Although the role of Allocasuarina spp. and the other Casuarina spp. as primary colonizers is not as evident, because the rate and scale of such processes in water-limited environments is more limited,

1) The appearance of the crown is superficially similar to some Pinus spp., which has led to the use of inaccurate and misleading common English names, such as Australian pine.

2) There is limited quantitative data on root system depth and structure of Allocasuarina and Casuarina species, but Pate et al. ${ }^{[67]}$ provides information for Allocasuarina humilis which is likely to be indicative of the group more widely. 
particularly for woody perennials, they like other actinorhizal plants will have this capacity. Once established, the heavy litter lay and nitrogen-rich root systems of sheoaks can serve to ameliorate hostile habitats, and thereby eventually facilitate natural or assisted succession ${ }^{[6]]}$.

These two genera also contain significant species diversity, and presumably local population (perhaps ecotype) diversity, with 66 species from Australia, some with extensive natural distribution (Table 2; Fig. 2; Fig. 3). So the opportunity to select suitable species or accessions is considerable. One final feature of this group is they are largely free of pests and diseases especially in low-rainfall environments, although, a number of diseases of C. equisetifolia have been recorded in nurseries and plantation in tropical India ${ }^{[76]}$.

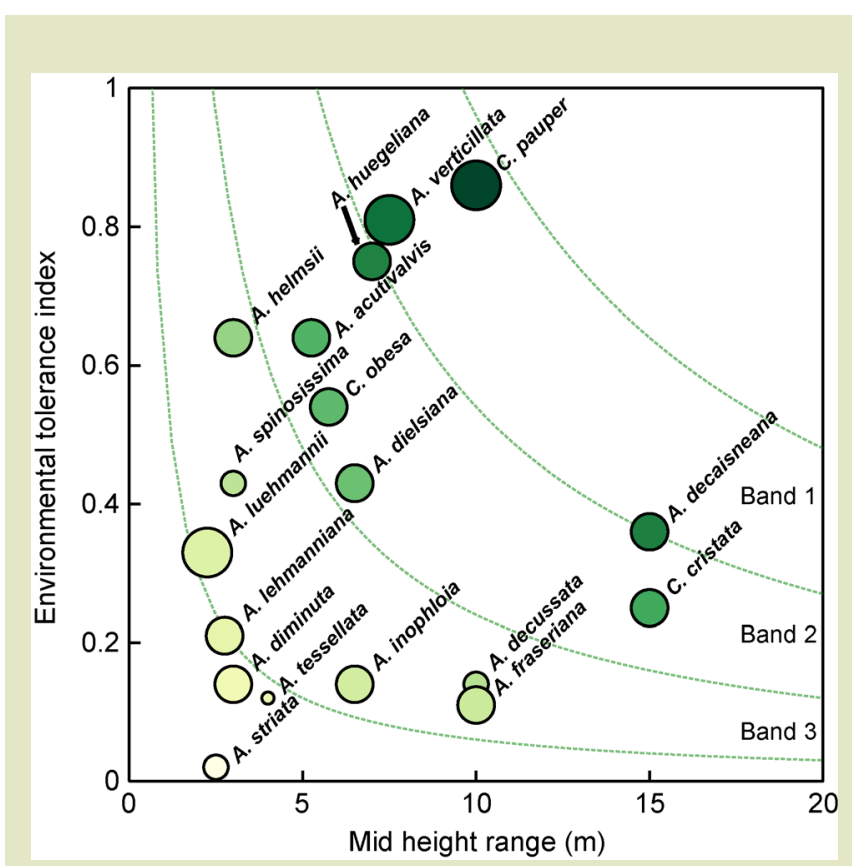

Fig. 3 Indicative environmental tolerance versus mid height range of Allocasuarina and Casuarina species that occur naturally in one or more moderate to high water- and heat-stress climatic zones (Köppen codes: BWh, BWk, BSh, BSk, Csa, Csb, see Fig. 1 and Table 2 for details). The provisional environmental tolerance index is the normalized sum of the of Köppen zones (numbered 1-6 in ascending order of stress) for those zones in which the species occurs naturally adjusted for the relative size of its range. The symbol size represents the relative range of the species (Table 2), and symbol color intensity indicative assessment priority (i.e., normalized square root of the area of the rectangle delimited by the coordinates of each point).

\subsection{Assessment and deployment risks}

Although an individual species, or group of species, may offer evident advantages for deployment in agroforestry or agroecosystem improvement, there will always be some risks. These risks occur in both the assessment and deployment phases, and might not even be evident as an issue for many years after deployment. When considering non-indigenous species, the most commonly perceived risk is potential invasiveness, that is, the risk the plant will naturalize and spread well beyond the intended range to cause both environmental and economic harm. For species not previously known to be invasive anywhere or even in the target context, it may take decades, especially for arboreal species, for this invasiveness to be evident. The very process of assessing exotic species also comes with a risk of concomitant introduction of associated pest and pathogens, which may themselves be invasive and spread to hosts/contexts beyond the introduced host. In addition to invasiveness, an eventual large scale deployment of a new plant species could lead to changes in fire risk, water tables and surface water collection, local flora and fauna, and even to landscapes in ways that are not readily accepted despite ecological or economic benefit.

Given that three Casuarina spp., and some other Australian trees, have become invasive in various countries, and some Australian eucalypts have been blamed for compromising ground water supplies and contributing to wildfires, consideration of the risks for low-rainfall-zone Allocasuarina and Casuarina species is important. There is no clear evidence that sheoaks from low-rainfall zones will present an invasiveness risk, and there are no records of them becoming naturalized beyond their native range. Likewise, the risk is low because of their relative freedom from pest and pathogens, and their taxonomic separation from the flora of similar climatic regions lowers the risk in this aspect. The Betulaceae is the most closely related family, but consist of largely temperate zone species. Sheoaks have low flammability ${ }^{[77]}$ so are not prone to canopy fires, and their litter burns slowly and the suppression of understory grasses means that can be used to prevent the spread of grass fires ${ }^{[66,78]}$. Being large shrubs to small trees they are also unlikely to have aggressively adverse effects on ground water, but also, this risk can be managed through the scale and location of deployment. So on balance, this group appears to be free of major risks, but any project to assess or deploy members of this group should regularly reassess this perception.

\section{ALLOCASUARINA AND CASUARINA SPP. SELECTION FOR ASSESSMENT}

If the proposition presented above is accepted, it would be 
ill-focused and impractical to attempt to collect and assess all 66 species. So, here a method to restrict this initial selection has been applied. First, only species that grow to $3 \mathrm{~m}$ or more were included, which reduced the number to 23 Allocasuarina spp. and 6 Casuarina spp. (Table 2). The cut-off of $3 \mathrm{~m}$ was chosen because in an agroecosystem context with grazing animals, it is considered that this would allow for persistence under light to moderate grazing. Although smaller shrubs can be useful (if not essential) in ecosystem rehabilitation ${ }^{[79]}$, here the focus is on the more arboreal species. Next, the native distribution of the species was obtained from online sources (Fig. 2), ranked on a relative scale and used to determine occurrence in the six water-limited Köppen climatic zones in Australia (Fig. 1; Table 2). Table 2 also provides information on plant statue and the common soils conditions in which they grow.

An indicative (semiquantitative) environmental tolerance index was calculated and used to help further restrict the range of species to those with the greatest potential suitability for Central Anatolia. The six Köppen zones were given a rank of one to six from the least to greatest degree of heat and water stress. For each species, the sum of these ranks for the zone in which they occurred was averaged and normalized, and then their normalized relative range used as a further adjustment factor. This process was based on an assumption that species with wider occurrence will tend to be more environmentally tolerant than those with narrower distribution. This tolerance index is plotted against the mid height range (Fig. 3), but only for species that occur in at least one of the six high-stress Köppen zones. C. cunninghamiana was excluded because it only occurs along inland watercourses in arid zones. The relative range is indicated by the symbol size. The mid height range is used as a simple surrogate for plant growth potential. However, although the positioning of the species in these two dimensions gives some indication of their relative merit, this has also been integrated and displayed as the increasing color intensity. The square root of the area of the rectangle prescribed by the coordinates of the species was used to allow grouping of species, taking into account contributions of both the tolerance index and height. This parameter is considered to be an indicator for comparative priority for assessment. Three bands of equivalent intensity have been added to the figure.

Using this analysis, A. verticillata and C. pauper (Band 1) are given highest priority, and A. acutivalvis, A. decaisneana, A. dielsiana, A. huegeliana, C. cristata and C. obesa secondary priority (Band 2). However, this relatively simple approach has its limitations. For example, mid height range is an indicator of accumulated growth not growth rate, per se. A. decaisneana grows to trees of remarkable size given the harshness of their desert environment, however, the large specimens are considered to be quite old and young specimens slow growing in nature, presumably because it has a particular adaptation for extreme aridity involving the allocation of a considerable proportion of photosynthates to root development; roots can grow $10 \mathrm{~m}$ deep ${ }^{[24,66,80]}$. So perhaps it might not be considered as particularly suited for early use in ecosystem restoration. Nevertheless, with trickle irrigation it is reported to reach $4 \mathrm{~m}$ within 6 years in a hot, arid environment, so its performance in less arid environment might be better than expected.

Otherwise, the species indicated in Bands 1 and 2 are those with moderate or higher growth potential and/or clear environmental tolerance over a moderate or higher range of water-limited environments, and most have some tolerance to either alkaline or saline soils. So the analysis appears to provide a reasonably starting point. Other factors that will need to be considered in advance or during the initial in vivo assessment include (1) potential availability of sufficient quantity of seed for future field-scale evaluation, (2) Frankia inoculum availability and compatibility, (3) ability to establish and grow in the common soils of the target area (in this case the calcareous and often shallow soils of Central Anatolia; Çullu et al. ${ }^{[1]}$ ) and root system performance in these soils, and (4) capacity to tolerate conditions beyond those in their native ranges (in this instance lower winter temperatures and snow cover).

\section{RECOMMENDATIONS}

The potential of Allocasuarina and Casuarina for wider economic and ecosystem has been recognized for many years. The first international Casuarina workshop ${ }^{[24]}$, in which the current author was a participant, recommended more systematic research across a wider range of taxa and provenances, but had a focus on silvicultural applications in humid to subhumid environments. It was noted that at that time many species, especially from Western Australia, had not been collected, studied or tested for use beyond their native range ${ }^{[24]}$. Although there have been some efforts to address this gap, progress has been limited, and Mediterranean to semi-arid agroecosystems have received little attention. In response, Ganguli and Kennedy ${ }^{[66]}$ have made a renewed call for wider evaluation and adoption of Allocasuarina and Casuarina in agricultural systems. So, joining these voices, again a call is made here for consideration of the Allocasuarina and Casuarina species as potentially useful contributors to agroecosystem improvement, and specifically so for Central Anatolia, a region with an unquestionable need for such protection and improvement as the threats of climate change become a reality. This assessment needs to commence with research cognizant of the biology of the 
plants ${ }^{[82]}$, and soil and climatic factors of the target region to ensure that initial efforts are not frustrated, and a recognition of the extended time needed for such an endeavor to achieve demonstrable gains.

\section{Acknowledgements}

This paper is dedicated to Dr. John Clemens (Adjunct Associate Professor, University of Canterbury, Christchurch, New Zealand), who first inspired the author in matters Casuarinaceae, and John W. Turnbull, former Chief Scientist at the Centre for International Forestry Research, Bogor, Indonesia, for his championing of efforts to see sheoaks used for their economic and environmental potential by Australia's neighbors in various parts of Asia. Gratitude is also extended to Dr. Halil Toktay for envisioning a new endeavor and Prof. Martin Barbetti for his unswerving encouragement. Prof. Drs. Ender Makineci, Istanbul University and Erol Akkuzu, Kastamonu University are thanked for their helpful comments.

\section{Compliance with ethics guidelines}

Ian T. Riley declares that he has no conflicts of interest or financial conflicts to disclose. This article is a review and does not contain any studies with human or animal subjects performed by the author.

\section{REFERENCES}

1. Australian Public Service Commission. Tackling wicked problems: a public policy perspective. Australian Public Service Commission, 2007

2. Slessarev E W, Lin Y, Bingham N L, Johnson J E, Dai Y, Schimel J P, Chadwick O A. Water balance creates a threshold in soil $\mathrm{pH}$ at the global scale. Nature, 2016, 540(7634): 567-569

3. Koohafkan P, Stewart B A. Water and cereals in drylands. Rome, Italy: Food and Agriculture Organization of the United Nations, 2008

4. Parr J F, Stewart B A, Hornick S B, Singh R P. Improving the sustainability of dryland farming systems: a global perspective. In: Singh R P, Parr J F, Stewart B A, eds. Advances in Soil Science. New York, USA: Springer New York, 1990, 1-8

5. Atalay I, Efe R, Öztürk M. Ecology and classification of forests in Turkey. Procedia: Social and Behavioral Sciences, 2014, 120: 788-805

6. Asouti E, Hather J. Charcoal analysis and the reconstruction of ancient woodland vegetation in the Konya Basin, south-central Anatolia, Turkey: results from the Neolithic site of Çatalhöyük East. Vegetation History and Archaeobotany, 2001, 10(1): 23-32

7. Woldring H, Cappers R. The origin of the "wild orchards" of Central Anatolia. Turkish Journal of Botany, 2001, 25(1): 1-9

8. Hughes J D. Ancient deforestation revisited. Journal of the History of Biology, 2011, 44(1): 43-57

9. Andrich M A, Imberger J. The effect of land clearing on rainfall and fresh water resources in Western Australia: a multifunctional sustainability analysis. International Journal of Sustainable Development and World Ecology, 2013, 20(6): 549563

10. Lawrence D, Vandecar K. Effects of tropical deforestation on climate and agriculture. Nature Climate Change, 2015, 5(1): 2736

11. Lund H G. What is a forest? Definitions do make a difference: an example from Turkey. Avrasya Terim Dergisi, 2014, 2(1): 1-8
12. Ministry of Environment and Urbanization. Republic of Turkey climate change strategy 2010 2023. Ankara, Turkey: General Directorate of Environmental Management Climate Change Office, Ministry of Environment and Urbanization, 2011

13. Tolunay A, Alkan H, Korkmaz M, Filiz Bilgin S. Classification of traditional agroforestry practices in Turkey. International Journal of Natural and Engineering Sciences, 2007, 1(3): 41-48

14. Lingley W S Jr, Jazdzewski S P. Aspects of growth management planning for mineral resource lands. Washington Geology, 1994, 22(2): $36-45$

15. Krawczyk R. Afforestation and secondary succession. Forest Research Papers, 2015, 75(4): 423-427

16. Prach K, Hobbs R J. Spontaneous succession versus technical reclamation in the restoration of disturbed sites. Restoration Ecology, 2006, 16(3): 363-366

17. Berrahmouni N, Regato P, Parfondry M. Global guidelines for the restoration of degraded forests and landscapes in drylands. Building resilience and benefiting livehoods. Rome, Italy: FAO (Food and Agriculture Organization of the United Nations), 2015

18. Camci Cetin S, Karaca A, Haktanir K, Yildiz H. Global attention to Turkey due to desertification. Environmental Monitoring and Assessment, 2007, 128(1-3): 489-493

19. Anonymous. Nearly half Turkey at risk of desertification. Daily Sabah. Istanbul, Turkey, 2015, Published online: December 1, 2015

20. Peel M C, Finlayson B L, McMahon T A. Updated world map of the Köppen-Geiger climate classification. Hydrology and Earth System Sciences, 2007, 11(5): 1633-1644

21. Turnbull J W. Australian Vegetation. In: Doran J, Turnbull J W, eds. Australian Trees and Shrubs: Species for Land Rehabilitation and Farm Planting in the Tropics. Canberra, Australia: Australian Centre for International Agricultural Research, 1997, 19-38

22. George A S. Flora of Australia. Vol. 3: Hamamelidales to 
Casuarinales. Canberra: Australian Government Publication Service, 1989

23. Hill R S. History of the Australian Vegetation: Cretaceous to Recent. Reprint. Adelaide, Australia: University of Adelaide Press, 2017

24. National Research Council. Casuarinas, nitrogen-fixing trees for adverse sites. Washington DC, USA: National Academy Press, 1984

25. El-Lakany M H, Turnbull J W, Brewbaker J L. Advances in Casuarina Research and Utilization: Proceedings of the Second International Workshop Cairo, Egypt January 15-20, 1990. Cairo, Eygpt: Desert Development Center, American University in Cairo, 1990

26. Pinyopusarerk K, Turnbull J W, Midgley J S. Recent Casuarina Research and Development: Proceedings of the Third International Casuarina Workshop, Da Nang, Vietnam, March 4-7, 1996. Canberra, Australia: CSIRO Forestry and Forest Products, 1996

27. Zhong C, Pinyopusarerk K, Kalinganire A, Franche C. Improving Smallholder Livelihoods Through Improved Casuarina Productivity: Proceedings of the Fourth International Casuarina Workshop. Beijing, China: China Forestry Publishing House, 2011

28. Nicodemus A, Pinyopusarerk K, Zhong C, Franche C. Casuarina Improvement for Securing Rural Livelihoods: Proceedings of the Fifth International Casuarina Workshop. Coimbatore, India: Institute of Forest Genetics and Tree Breeding, 2014

29. Potgieter L J, Richardson D M, Wilson J R U. Casuarina: biogeography and ecology of an important tree genus in a changing world. Biological Invasions, 2014, 16(3): 609-633

30. Nuberg I, George B, Reid R. Agroforestry for Natural Resource Management. Collingwood, Vic., Australia: CSIRO Publishing, 2009

31. Letnic M. Dispossession, degradation and extinction: environmental history in arid Australia. Biodiversity and Conservation, 2000, 9(3): 295-308

32. Bowman D M J S. Future eating and country keeping: what role has environmental history in the management of biodiversity? Journal of Biogeography, 2001, 28(5): 549-564

33. Henzell T. Australian agriculture: its history and challenges. Melbourne, Australia: CSIRO Publishing, 2007

34. McAlpine C A, Syktus J, Ryan J G, Deo R C, Mckeon G M, Mcgowan H A, Phinn S R. A continent under stress: interactions, feedbacks and risks associated with impact of modified land cover on Australia's climate. Global Change Biology, 2009, 15(9): 2206-2223

35. Lambers H. Dryland salinity: a key environmental issue in southern Australia. Plant and Soil, 2003, 257(2): V-VII

36. Harper R J, Gilkes R J, Hill M J, Carter D J. Wind erosion and soil carbon dynamics in south-western Australia. Aeolian Research, 2010, 1(3): 129-141

37. Haldon J, Roberts N, Izdebski A, Fleitmann D, McCormick M,
Cassis M, Doonan O, Eastwood W, Elton H, Ladstätter S, Manning S, Newhard J, Nicoll K, Telelis I, Xoplaki E. The climate and environment of Byzantine Anatolia: integrating science, history, and archaeology. Journal of Interdisciplinary History, 2014, 45(2): 131-161

38. Şenkul Ç, Ören A, Doğan U, Eastwood W J. Late Holocene environmental changes in the vicinity of Kültepe (Kayseri), Central Anatolia, Turkey. Quaternary International, 2018, 486: 107-115

39. Lelieveld J, Hadjinicolaou P, Kostopoulou E, Chenoweth J, El Maayar M, Giannakopoulos C, Hannides C, Lange M A, Tanarhte M, Tyrlis E, Xoplaki E. Climate change and impacts in the Eastern Mediterranean and the Middle East. Climatic Change, 2012, 114(3-4): 667-687

40. Kurt L, Ketenoglu O, Tug G N, Sekerciler F. Highland vegetation of inner and eastern Anatolia and the effects of global warming. Climate Change Impacts on High-Altitude Ecosystems. Cham, Switzerland: Springer, 2015, 275-288

41. Woldring H, Bottema S. The vegetation history of East-Central Anatolia in relation to archaeology: the Eski Acıgöl pollen evidence compared with the Near Eastern environment. Palaeohistoria, 2003, 43/44: 1-34

42. FAO. Save and grow: a policymaker's guide to the sustainable intensification of smallholder crop production. Rome, Italy: FAO, 2011

43. Türe C, Böcük H. Investigation of threatened arable weeds and their conservation status in Turkey. Weed Research, 2008, 48(3): 289-296

44. Boland J. Rainfall enhances vegetation growth but does the reverse hold? Water, 2014, 6(7): 2127-2143

45. Nuberg I, George B, Reid R. Agroforestry as integrated natural resource management. In: Nuberg I, George B, Reid R, eds. Agroforestry for Natural Resource Management. Collingwood, Vic., Australia: CSIRO Publishing, 2009, 1-20

46. Beech E, Rivers M, Oldfield S, Smith P P. GlobalTreeSearch: the first complete global database of tree species and country distributions. Journal of Sustainable Forestry, 2017, 36(5): 454489

47. Salt D, Freudenberger D. Biodiversity and habitat enhancement. In: Nuberg I, George B, Reid R, eds. Agroforestry for Natural Resource Management. Collingwood, Vic., Australia: CSIRO Publishing, 2009, 87-106

48. Balci Y, Halmschlager E. Phytophthora species in oak ecosystems in Turkey and their association with declining oak trees. Plant Pathology, 2003, 52(6): 694-702

49. Keten A, Beskardes V, Makineci E, Yilmaz E, Zengin H, Sevgi O, Yilmaz H C, Caliskan S. Hosts and distribution of yellow mistletoe (Loranthus europaeus Jacq. (Loranthaceae)) on Northern Strandjas Oak Forests-Turkey. Scientific Research and Essays, 2011, 6(14): 2970-2975

50. Gardner M, Knees S. Abies cilicica: the IUCN red list of threatened species 2013. Report No. e.T42275A2968944. International Union for Conservation of Nature, 2013 
51. Harvey-Brown Y, Barstow M, Mark J, Rivers M C. Populus nigra: the IUCN red list of threatened species 2017. Report No. e.T63530A68106816. International Union for Conservation of Nature, 2017

52. Yildiz O, Altundağ E, Çetin B, Teoman Güner Ş, Sarginci M, Toprak B. Experimental arid land afforestation in Central Anatolia, Turkey. Environmental Monitoring and Assessment, 2018, 190(6): 355

53. Collette L K D, Pither J. Russian-olive (Elaeagnus angustifolia) biology and ecology and its potential to invade northern North American riparian ecosystems. Invasive Plant Science and Management, 2015, 8(1): 1-14

54. Boydak M, Çalışkan S. Afforestation in arid and semi-arid regions. Ankara, Turkey: General Directorate of Combating Desertification and Erosion, Ministry of Forestry and Water Affairs, Republic of Turkey, 2015

55. Maranz S. Tree mortality in the African Sahel indicates an anthropogenic ecosystem displaced by climate change. Journal of Biogeography, 2009, 36(6): 1181-1193

56. BGCI. GlobalTreeSearch online database. Richmond, UK: Botanic Gardens Conservation International, 2018

57. Schlaepfer M A, Sax D F, Olden J D. The potential conservation value of non-native species. Conservation Biology, 2011, 25(3): 428-437

58. Hobbs R J, Higgs E, Harris J A. Novel ecosystems: implications for conservation and restoration. Trends in Ecology \& Evolution, 2009, 24(11): 599-605

59. Thomas S M, Palmer M W. The montane grasslands of the Western Ghats, India: community ecology and conservation. Community Ecology, 2007, 8(1): 67-73

60. Diagne N, Diouf D, Svistoonoff S, Kane A, Noba K, Franche C, Bogusz D, Duponnois R. Casuarina in Africa: distribution, role and importance of arbuscular mycorrhizal, ectomycorrhizal fungi and Frankia on plant development. Journal of Environmental Management, 2013, 128: 204-209

61. Zhong C, Zhang Y, Chen Y, Jiang Q, Chen Z, Liang J, Pinyopusarerk K, Franche C, Bogusz D. Casuarina research and applications in China. Symbiosis, 2010, 50(1-2): 107-114

62. Zhong C, Mansour S, Nambiar-Veetil M, Bogusz D, Franche C. Casuarina glauca: a model tree for basic research in actinorhizal symbiosis. Journal of Biosciences, 2013, 38(4): 815-823

63. Zhong C, Bai J, Zhang Y. Introduction and conservation of Casuarina trees in China. Forest Research, 2005, 18(3): 345-350 (in Chinese)

64. Castle W S, Langeland K A, Rockwood D L. Casuarina cunninghamiana Miq. (river sheoak) in Florida and its potential as a windbreak plant for citrus groves. Report No. HS1139. Gainesville, FL, USA: Horticultural Sciences Department, UF/ IFAS Extension, 2014

65. Torrey J G, Berg R H. Some morphological features for generic characterization among the Casuarinaceae. American Journal of Botany, 1988, 75(6): 864-874

66. Ganguli N K, Kennedy I R. Casuarina Leaf Litter: A Review. In:
Nicodemus A, Pinyopusarerk K, Zhong C, Franche C, eds. Casuarina Improvement for Securing Rural Livelihoods: Proceedings of the Fifth International Casuarina Workshop. Coimbatore, India: Institute of Forest Genetics and Tree Breeding, 2014, 52-58

67. Pate J S, Davidson N J, Kuo J, Milburn J A. Water relations of the root hemiparasite Olax phyllanthi (Labill) R.Br. (Olacaceae) and its multiple hosts. Oecologia , 1990, 84(2): 186-193

68. Becking J H. Frankiaceae fam. nov. (Actinomycetales) with one new combination and six new species of the genus Frankia Brunchorst 1886, 174. International Journal of Systematic and Evolutionary Microbiology, 1970, 20(2): 201-220

69. Diem H G, Duhoux E, Zaid H, Arahou M. Cluster roots in Casuarinaceae: role and relationship to soil nutrient factors. Annals of Botany, 2000, 85(6): 929-936

70. Brundrett M, Bougher N, Dell B, Grove T, Malajczuk N. Working with mycorrhizas in forestry and agriculture. Canberra, Australia: Australian Centre for International Agricultural Research, 1996

71. Atalay I. A new approach to the land capability classification: case study of Turkey. Procedia Environmental Sciences, 2016, 32: 264-274

72. CABI. Casuarina cunninghamiana. Invasive Species Compendium. Wallingford, UK: CAB International, 2018

73. CABI. Casuarina equisetifolia. Invasive Species Compendium. Wallingford, UK: CAB International, 2018

74. CABI. Casuarina glauca. Invasive Species Compendium. Wallingford, UK: CAB International, 2018

75. Jurskis V. Eucalypt decline in Australia, and a general concept of tree decline and dieback. Forest Ecology and Management, 2005, 215(1-3): 1-20

76. Mohanan C, Sharma J K. Diseases of Casuarina equisetifolia in India. Commonwealth Forestry Review, 1993, 72(1): 48-52

77. Grootemaat S, Wright I J, van Bodegom P M, Cornelissen J H C, Cornwell W K. Burn or rot: leaf traits explain why flammability and decomposability are decoupled across species. Schweitzer J, ed. Functional Ecology, 2015, 29(11): 1486-1497

78. Murphy S. Farm plantations can reduce bushfire risk. Recreating the Country, 2017. Available at Recreating the Country website on July 2, 2018

79. Castro J, Zamora R, Hódar J A, Gómez J M, Gómez-Aparicio L. Benefits of using shrubs as nurse plants for reforestation in Mediterranean mountains: a 4-year study. Restoration Ecology, 2004, 12(3): 352-358

80. Clarke M.The Red Centre Garden-starting from scratch. Fronds, 2012, (71): 10-11

81. Çullu M A, Günal H, Akça E, Kapur S. Soil Geography. In: Kapur S, Akça E, Günal H, eds. The Soils of Turkey. Cham, Switzerland: Springer International Publishing, 2018, 105-109

82. Reddell P, Diem H G, Dommergues Y R. Use of Actinorhizal Plants in Arid and Semiarid Environments. In: Skujins J, ed. Semiarid Lands and Deserts: Soil Resource and Reclamation. New York, USA: Marcel Dekker, 1991, 469-485 